\title{
Non-pharmacological aids for patients suffering from narcolepsy with cataplexy (White Paper 2021)
}

Dr. Carolina Diamandis ${ }^{1}$, Jacob S. Adams ${ }^{1}$, Anastasios Papadopoulos ${ }^{1}$, Riku Honda ${ }^{1}$, and David Seideman ${ }^{1}$

${ }^{1}$ Affiliation not available

May 12, 2021

\begin{abstract}
Narcolepsy with cataplexy is an often underestimated disorder in both its primary and secondary forms. As with epilepsy, narcolepsy and cataplexy pose a high risk of injury to the patient. Yet, narcoleptics have historically received poorer care than epileptics with regard to non-pharmacological aids. This "White Paper" informs both professionals and patients about protective measures that are advisable.
\end{abstract}

\section{Hosted file}

Help for patients with narcolepsy .pdf available at https://authorea.com/users/410930/ articles/521789-non-pharmacological-aids-for-patients-suffering-from-narcolepsy-withcataplexy-white-paper-2021 